\title{
Periorbital papules as a presenting sign in multiple myeloma with AL amyloidosis
}

\author{
Fathima Shahla Vilcassim, ${ }^{1,2,3}$ Michael Low, ${ }^{1,4,5}$ Pasquale Fedele, 1,4,5 \\ George Grigoriadis $1,2,3,6$
}

${ }^{1}$ Monash Haematology, Monash Health, Clayton, Victoria, Australia

${ }^{2}$ Monash University School of Clinical Sciences at Monash Health, Clayton, Victoria,

Australia

${ }^{3}$ Centre for Cancer Research Hudson Institute of Medical Research Clayton, Victoria, Australia

${ }^{4}$ Immunology/Molecular Immunology Division, Walter and Eliza Hall Institute of Medical Research, Melbourne, Victoria, Australia ${ }^{5}$ Department of Medical Biology, The University of Melbourne, Parkville, Victoria Australia

${ }^{6}$ Alfred Pathology Service and Department of Clinical Haematology, Alfred Health, Commercial Road, Melbourne Victoria Australia

\section{Correspondence to} Dr Fathima Shahla Vilcassim, shahla.vilcassim@ monashhealth.org

Accepted 6 February 2017

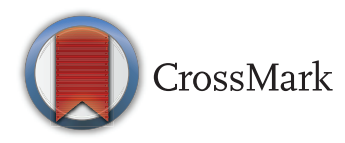

\begin{tabular}{|l|}
\hline To cite: Vilcassim FS, \\
Low M, Fedele P, et al. BMJ \\
Case Rep Published online: \\
[please include Day Month \\
Year] doi:10.1136/bcr-2016- \\
219010 \\
\hline
\end{tabular}

\section{DESCRIPTION}

A 67-year-old woman of Indian heritage with no significant medical history presented with a 9-month history of progressive periorbital lesions consisting of coalescing pigmented papules (figure 1A). On systems review she reported concurrent diarrhoea and weight loss. She was not in overt heart failure and had no other cutaneous lesions or macroglossia.

A biopsy of the lesions identified amorphous amphophilic material in the upper dermis (figure 1B), with positive staining for crystal violet, consistent with amyloid deposition. Further investigations demonstrated markedly elevated serum $\lambda$ light chains at $5423 \mathrm{mg} / \mathrm{L}$ with a ratio of $<0.01$ and a free $\lambda$ light chain paraprotein of $<2 \mathrm{~g} / \mathrm{L}$ with concurrent immuneparesis. A bone marrow biopsy demonstrated replacement of normal haematopoiesis

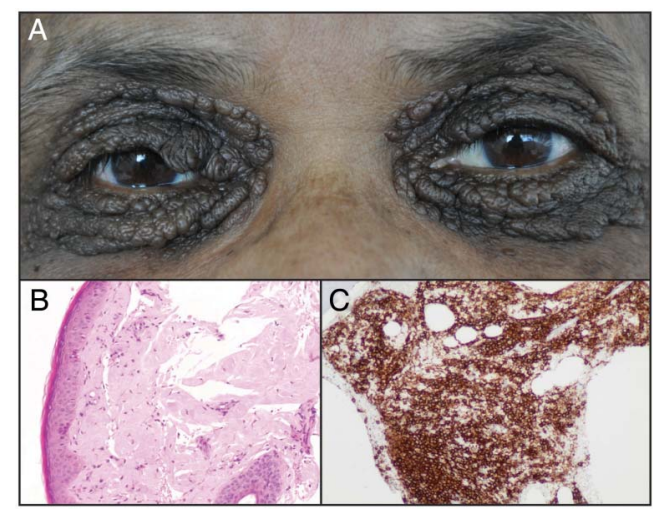

Figure 1 (A) Confluent periorbital lesions. (B) Deposition of pink amorphous material on histological section. (C) CD 138 positive plasma cell infiltrate on bone marrow trephine section. with plasma cells. CD138 immunohistochemical stain revealed $\sim 90 \%$ positivity (figure $1 \mathrm{C}$ ) consistent with the diagnosis of plasma cell myeloma complicated by light-chain amyloidosis. Further investigation for complications of amyloidosis revealed that she had nephrotic range proteinuria of $7 \mathrm{~g} /$ day with mild renal impairment but normal full blood examination, calcium level and coagulation profile. There was no evidence of cardiac involvement or bony disease.

\section{Learning points}

Amyloidosis can develop as either a systemic or limited cutaneous disease in which amyloid fibrils deposit in various tissues and organs causing organ failure.

- Periorbital lesions are known to occur in amyloid light-chain amyloidosis but are predominantly reported as purpuric lesions rather than coalescing papules.

- Early recognition of these signs is important for diagnosing and managing the underlying plasma cell dyscrasia as the prognosis relies on limiting the extent of end organ damage from amyloid deposition.

Contributors FSV, ML and PF managed the patient clinically during his illness. GG was instrumental in the assessment and interpretation of patient's pathological tests including bone marrow biopsy. All authors contributed to the writing of the manuscript.

Competing interests None declared.

Patient consent Obtained.

Provenance and peer review Not commissioned; externally peer reviewed.

Copyright 2017 BMJ Publishing Group. All rights reserved. For permission to reuse any of this content visit http://group.bmj.com/group/rights-licensing/permissions.

BMJ Case Report Fellows may re-use this article for personal use and teaching without any further permission.

Become a Fellow of BMJ Case Reports today and you can:

- Submit as many cases as you like

- Enjoy fast sympathetic peer review and rapid publication of accepted articles

- Access all the published articles

- Re-use any of the published material for personal use and teaching without further permission

For information on Institutional Fellowships contact consortiasales@bmjgroup.com

Visit casereports.bmj.com for more articles like this and to become a Fellow 